\title{
Bioelectricity from students' hostel waste water using microbial fuel cell
}

\author{
S.A. ADELEYE and S. I. OKORONDU* \\ Department of Microbiology, Federal University of Technology Owerri, NIgeria. \\ *Corresponding author; E-mail: sokorondu@yahoo.co.uk; thebrainbursterl@gmail.com
}

\begin{abstract}
Microbial fuel was constructed using two liter plastic transparent chambers representing the cathode and anode poles. The electrodes used were carbon and copper which were utilized in producing a carboncarbon and copper-copper fuel cells respectively. A $1 \%$ sodium chloride and $2 \%$ agar proton exchange membrane was used to connect both chambers of the fuel cells. Waste water generated from students' hostel in Federal University of Technology Owerri [FUTO], Nigeria, was used as the substrate for pitching both fuel cells. An initial voltage of $308 \mathrm{mV}$ and $338 \mathrm{mV}$ were recorded for both fuel cells. The voltage was monitored for 14 days. During this period a maximum of $0.81 \mathrm{~V}$ and 0.62 to $0.02 \mathrm{~V}$ were recorded for the copper-copper and carbon-carbon fuel cells, respectively. The voltage production resembled typical growth curve with the performance of the copper-copper fuel cell being better than the carbon - carbon fuel cell in consistency. When both fuel cells were connected in series, a combined voltage of $138 \mathrm{mV}(1.38 \mathrm{~V})$ was obtained indicating that arranging the cells in series yielded a maximum output. When the microbial biofilm of both electrodes were analyzed, the microbial population included both aerobic and anaerobic bacteria which included the following: Bacillus spp., Corynebacterium spp., Staphylococcus spp., Enterococcus spp. and Micrococcus spp. This research demonstrates that microorganisms have the capacity to produce electricity using domestic wastewater as substrate.
\end{abstract}

(C) 2015 International Formulae Group. All rights reserved.

Keywords: Microbial fuel cell, growth curve, bioelectricity, wastewater, electrodes.

\section{INTRODUCTION}

Environmentally friendly and sustainable energy production is coming to be the most pressing need in both research and world issues. Water and wastewater treatment are also a top priority in most developing global communities since it is generated on a daily basis. Some of the existing sources of energy are depleting, not ecofriendly, cheap and accessible and therefore the need for a cleaner and cheaper energy form (Ablisha and Sharma, 2009; Wen et al., 2009). Microbial fuel cells (MFCs) are alternative energy technologies that have the capacity to simultaneously treat wastewater and generate electricity. MFCs as a form of bioelectricity have experienced a recent surge in popularity within research circles due to their potential to address both of these world concerns (Dip et al., 2014; Kiely et al., 2011). There is 
therefore eventual goal of scaling up MFC technology for use with commercial and industrial applications. Moreover, further research is needed in many areas pertaining to design, configuration, and integration into existing technologies, operation and system stability (Du et al., 2007).

A microbial fuel cell or biological fuel cell is a device that converts chemical energy to electrical energy by the catalytic reaction of microorganisms (Allen and Bennetto, 1993). It is a bio-electrochemical system that drives a current by mimicking bacterial interactions found in nature. Organisms capable of producing an electric current are termed exoelectrogens. The concept of using microorganisms as catalysts in fuel cells was explored from the 1970s (Min et al., 2005). Microbial fuel cells used in treating domestic wastewater were presented in 1990s and has been exploited more in the new millennium (Min et al., 2005; Logan, 2007 and Moon et al., 2006). However, it is only recently that microbial fuel cells with enhanced power output have been developed providing possible opportunities for practical applications (Logan, 2007). A typical microbial fuel cell consists of anode and cathode compartments separated by a cation (positively charged ion) specific membrane. In the anode compartment, fuel is oxidized by microorganisms, generating electrons and protons. Electrons are transferred to the cathode compartment through an external electric circuit, while protons are transferred to the cathode compartment through the membrane. Electrons and protons are consumed in the cathode compartment, where they combine with oxygen to form water (Logan, 2007)

Two basic designs of microbial fuel cells include the single chamber and double chamber (e.g. the conventional H-type design used in this work) microbial fuel cells (Logan, 2007; Jincheng et al., 2011). Modifications exists in electrode configurations (Yongtae et al., 2014), catholyte and proton exchange membrane (Logan, 2007). Sodium chloride is believed to increase the conductivity of the anolyte and the catholyte when added in concentrations that will not be toxic to the microbial community (Gil et al., 2003; Jang et al., 2004)

The objective of this research was to show that microorganisms have the potential to generate electricity and can therefore serve as a means of electricity generation from wastewater. It was targeted at proposing a method of generating energy (electricity) from wastewater.

\section{MATERIALS AND METHODS Sample collection}

The wastewater was collected from a school hostel at a mini-dam where waste effluents flow through. It was collected on the day of the analysis in order to prevent the degradation of the organic content of the sample by microorganisms. The organic content is the target substrate for the microbial oxidation which will produce the electrons desired in MFC set up.

\section{Preparation of the salt bridge}

The salt bridge was prepared using $2 \%$ Agar-agar and $1 \% \mathrm{NaCl}$. A $10 \mathrm{~cm}$ salt bridge was made using a PVC $1 / 2$ inch pipe. Firstly, 2 $\mathrm{g}$ of agar-agar and $1 \mathrm{~g}$ of sodium chloride was added to $100 \mathrm{ml}$ of water in a conical flask. It was then dissolved by swirling the conical flask. The mixture prepared was autoclaved. One end of a PVC tube is sealed with polythene or nylon in an easily detachable way and held standing vertically using a soft support. The autoclaved mixture was allowed to cool to about $50{ }^{0} \mathrm{C}$ to $55{ }^{0} \mathrm{C}$ before it is emptied into the PVC tube in the soft support. This is then allowed to cool and solidify thereby forming the salt bridge which is used for the MFC set up. 


\section{Constructing the cathode and anode chambers}

A 2 1-litre plastic cathode and anode was purchased. A hole, equal in diameter to the $1 / 2$ inch adopter used for plumbing work is made $7 \mathrm{~cm}$ from the base of the 1-liter tank base. The $1 / 2$ inch adopter serves as a point of attachment for the salt bridge which is posed to interconnect the two chambers. After the hole is made, the $1 / 2$ inch adopter was glued using Topgit gum (available in plumbing stores). The gum was mixed with ash and then used to seal the edges of the point of contact between the $1 / 2$ inch adopter with the chamber to avoid leakages. Next, a hole each was drilled into the lid of both chambers to allow the passage of wire and an extra hole for the cathode chamber which will allow passive aeration of the cathode chamber. The set-up was allowed to dry and solidify.

\section{Preparation of graphite and copper electrodes}

Equal-diameter, equal-length copper electrodes were purchased commercially as two separate electrodes with a screw cap allowing attachments for wire. These are readily made for experimental purpose. Graphite rods (obtained from dismantled dry cells) were joined using copper wire in set of four to encourage a greater surface area for biofilm formation.

\section{Coupling the microbial fuel cell}

The salt bridge was made a day before the set-up is coupled. The sample was collected the same day the set-up was to be coupled. The set-up was coupled by joining the two chambers using the salt bridge with the aid of the adopter inch using Topgit gum. The waste water was placed into the anode as the anolyte and $0.01 \% \mathrm{NaCl}$ was added to aid the flow of ions via the proton exchange membrane. $5 \%$ glucose was added to the cathode as the catholyte. The lid of the chambers was used to passively aerate the cathode using oxygen as the terminal electron acceptor. The multimeter is connected to the cathode and the anode with the aid of the low resistance wire before they are inserted into the chambers. Next the multimeter is set at $2000 \mathrm{~m}$ for measuring DC current in millivolts. The initial reading was taken at time 00 and allowed to acclimatize for three hours before subsequent readings are taken. Figure 1 shows a complete microbial fuel cell set up as explained above.

\section{Microbial community}

Microorganisms isolated from the samples were characterized based on the colonial, morphological, microscopic and biochemical characteristics of the pure cultures. The identities of the isolates were cross matched with features obtained in standard microbiological procedures (Cheesbrough, 2000; Buchannan and Gibbon, 1974).

\section{RESULTS \\ Voltage production}

On addition of the wastewater as substrate for both fuel cells, the initial reading of the startup voltage was recorded. This was followed by an hourly reading for a 12-14 hours interval. Records of the voltage output were taken hourly over a 12 to 14 hours period daily for 14 days. The data obtained was analysed and statistics was produced with the aid of Microsoft Excel 2013. An average voltage obtained from each fuel cell was obtained from the daily readings. Also the minimum and maximum voltage produced by each fuel cell was also recorded daily. The integrated statistics obtained from the 14 days period revealed that the maximum voltage obtained from both fuel cells is $833 \mathrm{mV}$. A better performance was observed from copper electrode fuel cell having $833 \mathrm{mV}$ on the $9^{\text {th }}$ and $14^{\text {th }}$ day. The maximum voltage from the carbon electrode fuel cell is $677 \mathrm{mV}$ which was obtained on the $2^{\text {nd }}, 9^{\text {th }}, 13^{\text {th }}$ and $14^{\text {th }}$ day respectively. The minimum voltage observed from the copper and carbon electrode fuel cell 
ware $308 \mathrm{mV}$ and $338 \mathrm{mV}$ which represent their first day readings respectively

The graph of average voltage $(\mathrm{mV})$ produced by each fuel cell was plotted against time (days) over the 14 days period. Also the actual voltage $(\mathrm{mV})$ produced daily by the fuel cells was also plotted against time in hours over the 14 days period. The graphs were plotted using Microsoft excel 2013. The highest peak represented the maximum voltage while the lowest point represents the lowest voltage produced. The graph indicated a growth-curve pattern. Figure 2 shows the average voltage produced over a 14 day period while Figure 3 represents an hourly value of voltage produced by the microbial fuel cell.

\section{Microbial community}

The microbial community in the microbial fuel cells were identified using standard biochemical tests and the results of the biochemical test is shown in Tables 1,2 and 3 . The community assessment revealed the presence of both gram positive and gram negative organisms. Among the organisms isolated, Bacillus spp., Bacillus subtilis, Enterococcus faecalis, Enterobacter spp. and Corynebacterium spp. are gram negatives while Staphylococcus spp. and Micrococcus spp. are gram positives.

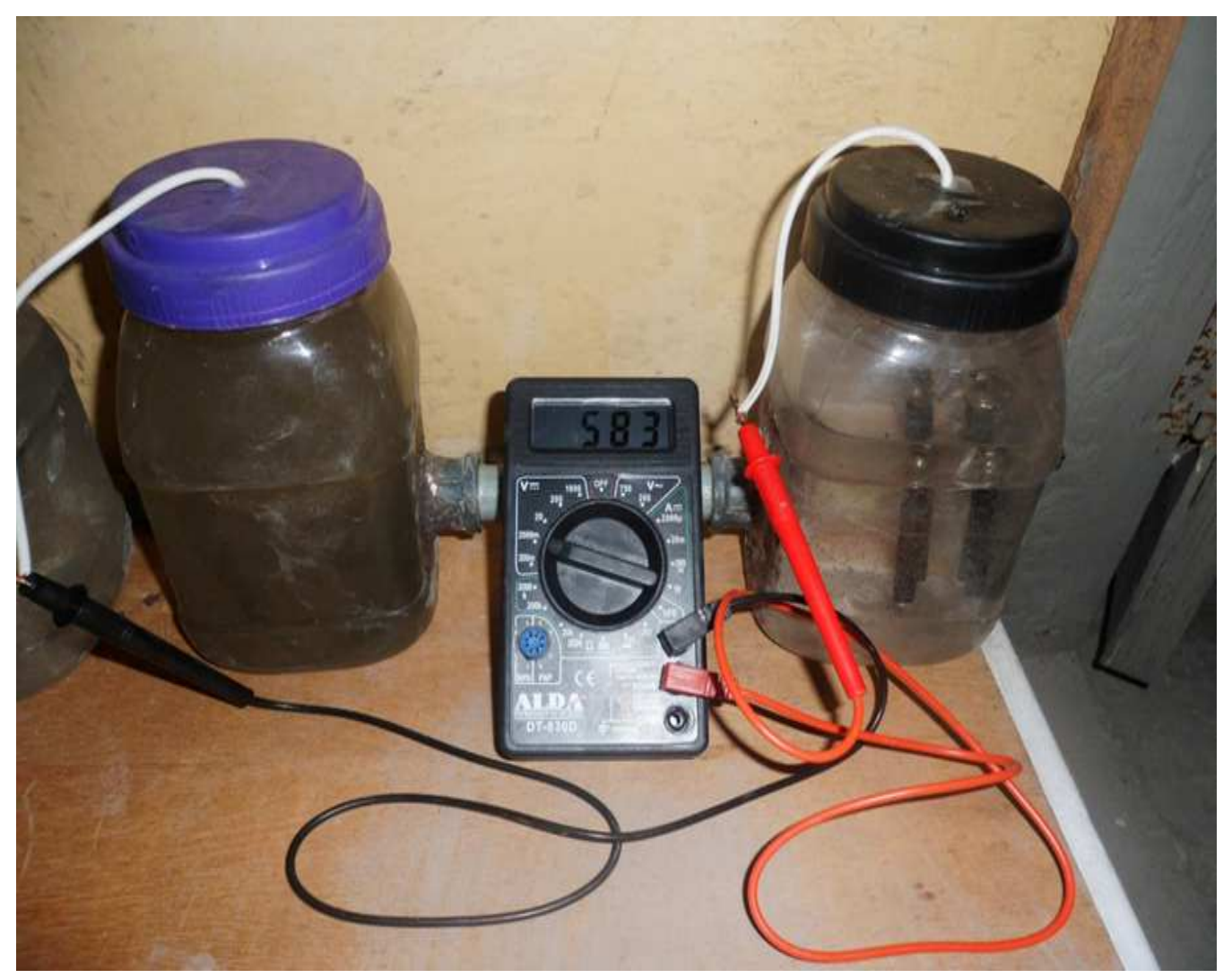

Figure 1: A complete set up of a H-type microbial fuel cell using carbon electrodes. 


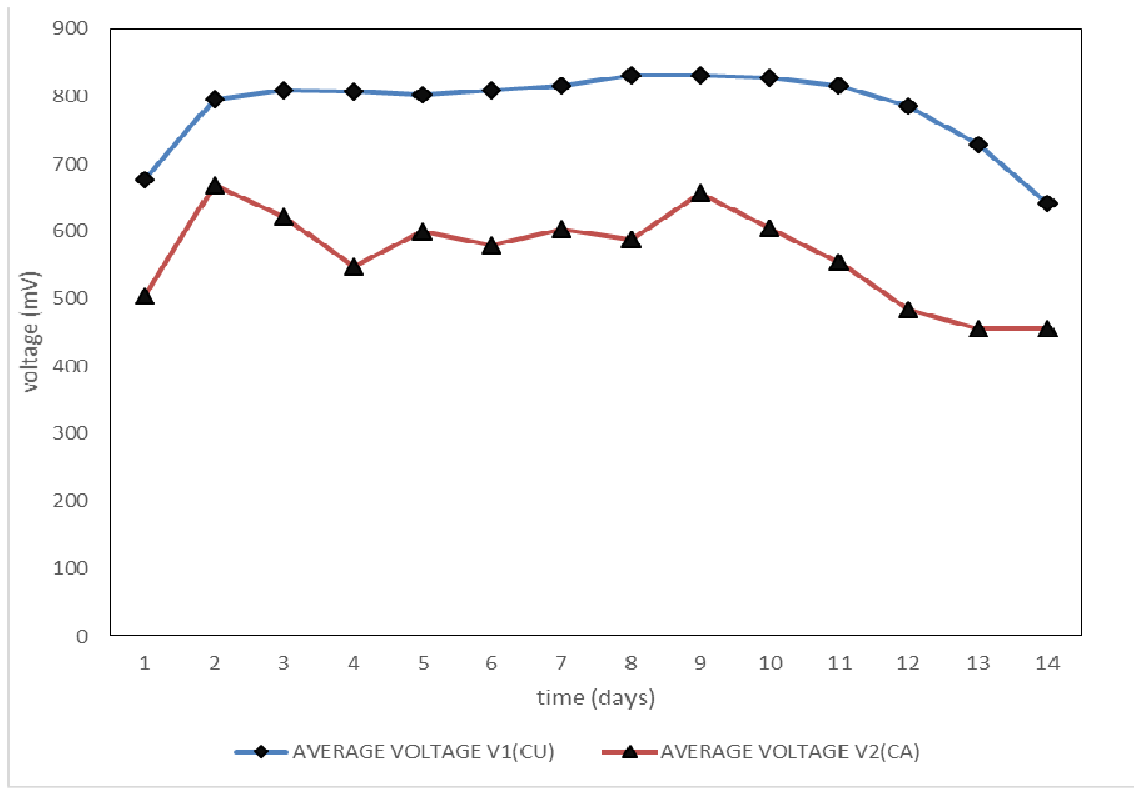

Figure 2: Average voltage produced over the 14 days period by $\operatorname{copper}(\mathrm{Cu})$ and carbon electrode(Ca) microbial fuel cell.

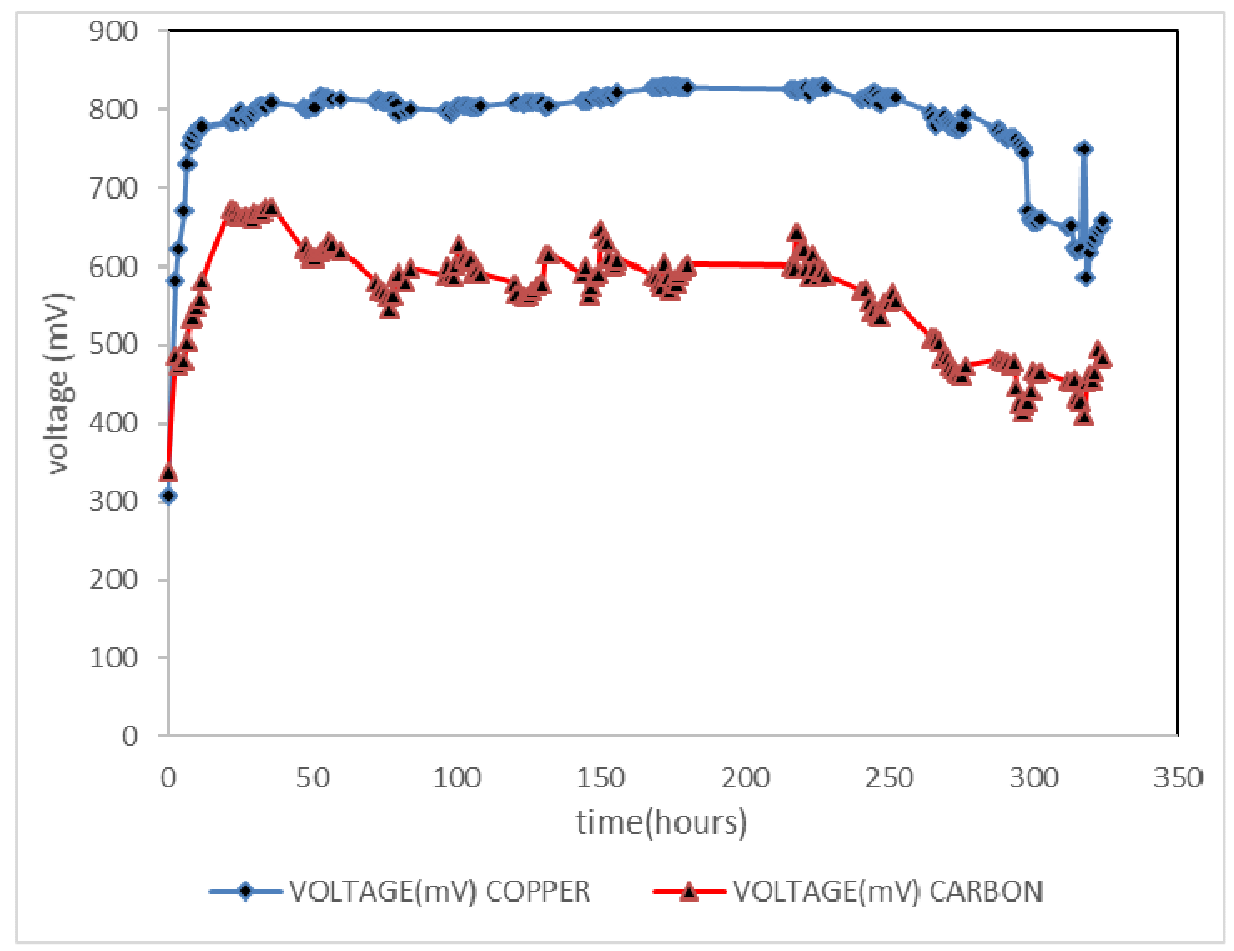

Figure 3: Voltage against time (hours) over the 14 days period. 
S.A. ADELEYE and S. I. OKORONDU / Int. J. Biol. Chem. Sci. 9(2): 1038-1049, 2015

Table 1: Biochemical tests of bacteria isolated from electrodes.

\begin{tabular}{|c|c|c|c|c|c|c|c|c|c|c|c|c|c|c|c|c|}
\hline \multirow[t]{2}{*}{ Colony code } & \multirow[t]{2}{*}{ Cat } & \multirow[t]{2}{*}{ Oxi } & \multirow[t]{2}{*}{ Coag } & \multirow[t]{2}{*}{ In } & \multirow[t]{2}{*}{ MR } & \multirow[t]{2}{*}{$\mathbf{V P}$} & \multirow[t]{2}{*}{ Cit } & \multirow[t]{2}{*}{$\mathrm{NO}_{3}$} & \multirow[t]{2}{*}{ urease } & \multicolumn{6}{|c|}{ Carbohydrate fermentation } & \multirow[t]{2}{*}{ probable identification } \\
\hline & & & & & & & & & & Glu & Suc & Mal & Lac & Mann & Xyl & \\
\hline $\mathrm{C}_{\mathrm{c} 1}$ & + & - & - & - & - & + & + & + & - & + & - & - & $t^{\mathrm{s}}$ & + & + & Bacillus subtilis \\
\hline $\mathrm{C}_{\mathrm{c} 2}$ & - & - & - & - & + & - & + & - & - & + & + & - & + & + & - & Enterococcus faecalis \\
\hline $\mathrm{C}_{\mathrm{c} 3}$ & + & - & - & - & - & + & + & + & - & + & - & - & - & - & - & Bacillus spp. \\
\hline $\mathrm{C}_{\mathrm{a} 1}$ & + & - & - & - & - & + & + & + & - & + & - & - & - & - & - & Bacillus spp. \\
\hline $\mathrm{C}_{\mathrm{a} 2}$ & + & - & - & - & - & + & + & + & - & + & - & - & $+^{\mathrm{s}}$ & + & + & Bacillus subtilis \\
\hline $\mathrm{C}_{\mathrm{a} 3}$ & - & - & - & - & + & - & + & - & - & + & + & - & + & + & - & Enterococcus faecalis \\
\hline $\mathrm{C}_{\mathrm{a} 4}$ & + & - & - & - & - & + & + & + & - & + & - & - & $t^{\mathrm{s}}$ & + & + & Bacillus subtilis \\
\hline $\mathrm{CU}_{\mathrm{c} 1}$ & - & - & - & - & + & - & + & - & - & + & + & - & + & + & - & Enterococcus faecalis \\
\hline $\mathrm{CU}_{\mathrm{c} 2}$ & + & - & - & - & - & + & + & + & - & + & - & - & $t^{s}$ & + & + & Bacillus subtilis \\
\hline $\mathrm{CU}_{\mathrm{a} 1}$ & + & - & - & - & - & + & + & + & - & + & - & - & $+^{\mathrm{s}}$ & + & + & Bacillus subtilis \\
\hline $\mathrm{CU}_{\mathrm{a} 2}$ & + & - & - & - & - & + & + & + & - & + & - & - & $t^{\mathrm{s}}$ & + & + & Bacillus subtilis \\
\hline $\mathrm{C}_{\mathrm{ca}}$ & + & - & - & - & - & + & + & + & - & + & - & - & - & - & - & Bacillus spp. \\
\hline $\mathrm{C}_{\mathrm{cb}}$ & + & - & - & - & - & - & + & + & + & + & + & + & - & + & - & Staph. spp. \\
\hline $\mathrm{C}_{\mathrm{cc}}$ & - & - & - & - & + & - & + & - & - & + & + & - & + & + & - & Enterococcus faecalis \\
\hline $\mathrm{C}_{\mathrm{aa}}$ & - & - & - & - & + & - & + & - & - & + & + & - & + & + & - & Enterococcus faecalis \\
\hline $\mathrm{C}_{\mathrm{ab}}$ & + & - & - & - & - & - & + & + & + & + & + & + & - & + & - & Staph. spp. \\
\hline $\mathrm{C}_{\mathrm{ac}}$ & + & - & - & - & - & + & + & + & - & + & - & - & - & - & - & Bacillus spp. \\
\hline $\begin{array}{l}\mathrm{C}_{\mathrm{c}}=\text { sample collec } \\
\mathrm{C}_{\mathrm{a}}=\text { sample collec } \\
\mathrm{CU}_{\mathrm{c}}=\text { sample coll } \\
\mathrm{CU}_{\mathrm{a}}=\text { sample coll } \\
+=\text { positive } \\
-=\text { negative }\end{array}$ & $\begin{array}{l}\text { from } \\
\text { rom }\end{array}$ & iofiln & $\begin{array}{l}\text { irbon cat } \\
\text { rbon an } \\
\text { copper c } \\
\text { carbon a }\end{array}$ & $\begin{array}{l}\text { de, } \\
\text { e, } \\
\text { hode, } \\
\text { de. }\end{array}$ & & & & & & & & & & & & \\
\hline
\end{tabular}


S.A. ADELEYE and S. I. OKORONDU / Int. J. Biol. Chem. Sci. 9(2): 1038-1049, 2015

Table 2: Biochemical tests of bacteria isolated from electrodes (continued).

\begin{tabular}{|c|c|c|c|c|c|c|c|c|c|c|c|c|c|c|c|c|}
\hline \multirow[t]{2}{*}{ Colony code } & \multirow[t]{2}{*}{ Cat } & \multirow[t]{2}{*}{ Oxi } & \multirow[t]{2}{*}{ Coag } & \multirow[t]{2}{*}{ In } & \multirow[t]{2}{*}{ MR } & \multirow[t]{2}{*}{$\mathbf{V P}$} & \multirow[t]{2}{*}{ Cit } & \multirow[t]{2}{*}{$\mathrm{NO}_{3}$} & \multirow[t]{2}{*}{ urease } & \multicolumn{6}{|c|}{ Carbohydrate fermentation } & \multirow[t]{2}{*}{ Identification } \\
\hline & & & & & & & & & & Glu & Suc & Mal & Lac & Mann & Xyl & \\
\hline $\mathrm{CU}_{\mathrm{ca}}$ & + & - & - & - & - & - & + & + & + & + & + & + & - & + & - & Staph. spp. \\
\hline $\mathrm{CU}_{\mathrm{aa}}$ & + & - & - & - & - & + & + & + & - & + & - & - & - & - & - & Bacillus spp. \\
\hline $\mathrm{CU}_{\mathrm{ab}}$ & - & - & - & - & + & - & + & - & - & + & + & - & + & + & - & Enterococcus faecalis \\
\hline $\mathrm{CU}_{\mathrm{ac}}$ & + & - & - & - & - & + & + & + & - & + & - & - & - & - & - & Bacillus spp. \\
\hline $\mathrm{C}_{\mathrm{cx}}$ & + & - & - & - & - & - & + & + & + & + & + & + & - & + & - & Staph. spp. \\
\hline $\mathrm{C}_{\mathrm{ax}}$ & + & - & - & - & - & - & + & + & + & + & + & + & - & + & - & Staph. spp. \\
\hline $\mathrm{C}_{\mathrm{ay}}$ & + & - & - & - & - & + & - & - & - & + & + & - & + & + & + & Enterobacter spp. \\
\hline $\mathrm{CU}_{\mathrm{ax}}$ & + & - & - & - & - & + & - & - & - & + & + & - & + & + & + & Enterobacter spp. \\
\hline $\mathrm{CU}_{\mathrm{ay}}$ & + & - & - & - & - & - & + & + & + & + & + & + & - & + & - & Staph. spp. \\
\hline $\mathrm{CU}_{\mathrm{az}}$ & + & - & - & - & - & + & + & + & - & + & - & - & - & - & - & Bacillus spp. \\
\hline $\mathrm{CU}_{\mathrm{cx}}$ & + & - & - & - & - & - & + & + & + & + & + & + & - & + & - & Staph. spp. \\
\hline $\mathrm{C}_{\mathrm{au}}$ & + & - & - & - & - & - & + & + & + & + & + & + & - & + & - & Staph. spp. \\
\hline $\mathrm{C}_{\mathrm{av}}$ & + & - & - & - & - & - & + & + & + & + & + & + & - & + & - & Staph. spp. \\
\hline $\mathrm{CU}_{\mathrm{au}}$ & + & - & - & - & - & - & + & + & + & + & + & + & - & + & - & Staph. spp. \\
\hline
\end{tabular}

$\mathrm{C}_{\mathrm{c}}=$ sample collected from the biofilm on carbon cathode,

$\mathrm{C}_{\mathrm{a}}=$ sample collected from the biofilm on carbon anode,

$\mathrm{CU}_{\mathrm{C}}=$ sample collected from the biofilm on copper cathode,

$\mathrm{CU}_{\mathrm{a}}=$ sample collected from the biofilm on carbon anode.

$+=$ positive

- = negative

$\mathrm{A}, \mathrm{b}, \mathrm{c}, 1,2,3, \mathrm{u}, \mathrm{v}, \mathrm{x}, \mathrm{Z}$ are used to indicate the different isolates from the same sample source. 
S.A. ADELEYE and S. I. OKORONDU / Int. J. Biol. Chem. Sci. 9(2): 1038-1049, 2015

Table 3: Biochemical tests of bacteria isolated from electrodes (continued).

\begin{tabular}{|c|c|c|c|c|c|c|c|c|c|c|c|c|c|c|c|c|c|}
\hline \multirow[t]{2}{*}{ Colony code } & \multirow[t]{2}{*}{ Cat } & \multirow[t]{2}{*}{ Oxi } & \multirow[t]{2}{*}{ Coag } & \multirow[t]{2}{*}{ In } & \multirow[t]{2}{*}{ MR } & \multirow[t]{2}{*}{ VP } & \multirow[t]{2}{*}{ Cit } & \multirow[t]{2}{*}{$\mathrm{NO}_{3}$} & \multirow[t]{2}{*}{ urease } & \multicolumn{7}{|c|}{ Carbohydrate fermentation } & \multirow[t]{2}{*}{ Identification } \\
\hline & & & & & & & & & & Glu & Suc & Mal & Lac & Mann & Xyl & Ara & \\
\hline $\mathrm{C}_{\mathrm{ca}}$ & + & - & - & - & - & - & + & + & + & + & + & + & - & + & - & - & Staph. aureus \\
\hline $\mathrm{C}_{\mathrm{cb}}$ & + & - & - & - & - & + & + & - & - & - & - & - & - & - & - & - & M. luteus. \\
\hline $\mathrm{C}_{\mathrm{cc}}$ & + & - & - & - & + & - & + & + & - & + & + & - & - & - & - & - & Corynebacterium spp. \\
\hline $\mathrm{C}_{\mathrm{cd}}$ & + & - & - & - & - & + & + & - & - & - & - & - & - & - & - & - & M. luteus. \\
\hline $\mathrm{C}_{\mathrm{ce}}$ & + & - & - & - & - & + & + & - & - & + & + & - & - & - & - & - & M. roseus. \\
\hline $\mathrm{C}_{\mathrm{a} 1}$ & + & - & - & - & - & + & + & + & - & + & - & - & $t^{\mathrm{s}}$ & + & + & - & Bacillus subtilis \\
\hline $\mathrm{C}_{\mathrm{a} 2}$ & + & - & - & - & - & + & + & - & - & - & - & - & - & - & - & - & M. luteus. \\
\hline $\mathrm{C}_{\mathrm{a} 3}$ & + & - & - & - & - & + & + & - & - & + & + & - & - & - & - & - & M. roseus. \\
\hline $\mathrm{C}_{\mathrm{a} 4}$ & + & - & - & - & - & + & + & - & - & - & - & - & - & - & - & - & M. luteus. \\
\hline $\mathrm{C}_{\mathrm{a} 5}$ & + & - & - & - & - & + & - & + & + & + & + & + & + & - & + & + & Staph. saprophyticus \\
\hline $\mathrm{CU}_{\mathrm{a} 1}$ & + & - & - & - & - & + & + & - & - & - & - & - & - & - & - & - & M. luteus. \\
\hline $\mathrm{CU}_{\mathrm{a} 2}$ & + & - & - & - & - & + & - & + & + & + & + & + & + & - & + & + & Staph. saprophyticus \\
\hline $\mathrm{CU}_{\mathrm{a} 3}$ & + & - & - & - & - & - & + & + & + & + & + & + & - & + & - & - & Staph. Aureus \\
\hline $\mathrm{CU}_{\mathrm{c} 1}$ & + & - & - & - & - & + & + & - & - & - & - & - & - & - & - & - & M. luteus. \\
\hline $\mathrm{CU}_{\mathrm{c} 2}$ & + & - & - & - & - & + & + & - & - & + & + & - & - & - & - & - & M. roseus. \\
\hline
\end{tabular}

$\mathrm{C}_{\mathrm{c}}=$ sample collected from the biofilm on carbon cathode,

$\mathrm{C}_{\mathrm{a}}=$ sample collected from the biofilm on carbon anode,

$\mathrm{CU}_{\mathrm{C}}=$ sample collected from the biofilm on copper cathode,

$\mathrm{CU}_{\mathrm{a}}=$ sample collected from the biofilm on carbon anode.

+ = positive; - = negative; A,b,c, 1,2,3 are used to indicate the different isolates from the same sample source. 


\section{DISCUSSION}

The design adopted the use of sodium chloride $(\mathrm{NaCl})$ as an enhancer of ionic activity of the electrolytes. Electricity generation in MFCs is a function of various physicochemical as well as biological parameters (Rajesh et al., 2008). $\mathrm{NaCl}$ is generally used as the electrolyte to improve the mass transfer of charged particles and to increase the solution conductivity (Gil et al., 2003). Also, Proton availability to the cathode is a limiting factor in electricity generation. Increasing ionic strength by adding $\mathrm{NaCl}$ to MFCs also improved the power output (Jang et al., 2004) possibly due to the fact that $\mathrm{NaCl}$ enhanced the conductivity of both by anolyte and the catholyte (Gil et al., 2003; Jang et al., 2004). In addition to the use of $\mathrm{NaCl}$, rods of carbon and copper served as electrodes. Several other configurations exist for electrodes and electrode materials (Yongtae et al., 2014)

At the beginning of the experiment, it was observed that the voltage was low and recorded as $308 \mathrm{mV}$ and $338 \mathrm{mV}$ for the copper and carbon electrode microbial fuel cells respectively. This was followed by an extended period in which the voltage was seriously fluctuating. As stated by Logan (2007) "In an MFC it takes time for the bacteria to colonize the electrode and manufacture enzymes or structures needed to transfer electrons outside the cell. In mixed cultures, different bacteria grow, setting different potentials". This clearly explains the extended period of acclimatization experienced in the experiment. The average output for the first day was recorded as 673 $\mathrm{mV}$ and $503 \mathrm{mV}$ or the copper and carbon electrode microbial fuel cells respectively. After three days, voltage produced by the cupper electrode was constant as $0.81 \mathrm{~V}$ approximately. Carbon on the other hand, produced an approximated value of $0.62 \pm 2 \mathrm{~V}$ after 2-3days. This clearly represents the period of exponential growth where the organisms (electricigens) are actively utilizing the organics in the wastewater for energy. Later, towards the end of the 14 days period, the voltage began to fluctuate again. This was followed by a period of rapid voltage drop. These were attributed to the fact that these organisms were using up the organic matter in the wastewater as well as accumulating toxic metabolites produced to aid inter and intraspecies competition and are therefore gradually entering into the decline phase of growth (Peleg, 2006; McKellar, 2004).

During the logarithmic phase of the microorganisms, it is characterized by rapid growth, and the individual morphology, chemical composition, physical characteristics of the organisms are more variable. Conversely, the stationary phase of a microorganism will achieve a maximum growth number of bacteria and reach quasiequilibrium between the cell sorting and cell death crack speeds. The effect of culture time with respect to the different microbial community and the influence of the growth curve phase on electricity performance of microbial fuel cell would represent the different characteristics of growth and further affect the power performance (Chin-Tsan et al., 2010). Generally speaking, the phase at the middle of the logarithmic phase or transition from logarithmic to stationary phase would have a better power performance appear because the phase would show a stronger growth rate and a higher metabolism. These observations would be useful to improve the performance of MFCs (ChinTsan et al., 2010).

In this study, copper was producing more voltage. This could be because copper is a reactive metal and may give rise to spurious generation of current by electrochemical dissolution of the metal (Bennetto, 1990). Electrochemistry could be attributed to the production of current from wastewater due an 
electrochemical potential produced by ions that may be present in the wastewater. Moreover, the voltage produced will not increase if it were to be the case but rather experience a decline rapidly or gradually as a result of chemical decomposition and electrochemical defects (Feng, 2008). Here, the voltage measured in the beginning of the experiment was the least produced as it increased gradually until the decline phase is reached. The bacterial community around the biofilm indicated the presence of both gram positive and gram negative strains of bacteria. Exoelectrogens are most prominent in organisms associated with biofilm formation (Wudneh et al., 2014). Moreover, Molecular characterization of MFC biofilm communities to date shows that our knowledge of electrochemically active bacteria, and their interactions in biofilms, remains inadequate. This implies the need to formulate better methods which can be used to identify adequately and characterize the bacterial communities in MFCs other than the methods applied in this work.

Microbial population revealed Bacillus spp., Bacillus subtilis, Enterococcus faecalis, Enterobacter spp., Staphylococcus spp., Micrococcus spp. and Corynebacterium spp following their identification using biochemical tests as shown in Tables 1,2 and 3. This research revealed possibilities of upgrading and obtaining greater output by arranging the cells in series. It was also observed that there is usually an effect characterized by an increase in voltage when the set-up is agitated during the experiment. Thus, more work need to be done to ascertain these effects. Temperature parameters though not reported indicated increase in voltage during the day than at nights. It is also important to state here that the wastewater physical parameter (colour) was monitored and there was an observed paleness in the colour after the end of the experiment however no wastewater parameter was monitored. This could support the thesis that microbial fuel cells are not only used for power generation but also for effective waste water treatment (Logan, 2007; Oh and Logan, 2005; Sonal, 2014; Ghangrekar and Shinde, 2006; You et al., 2006).

\section{Conclusion}

Microbial fuel cells can be used to generate electrical energy by using any Biowaste material that contains significant amount of organic matter such as carbohydrates, proteins and lipids, etc. Microorganisms utilize organic matter and produce electrons which could be captured artificially using a natural electron acceptor such as oxygen. Microbial catalyzed fuel cells could be the best alternative of fossil fuels to overcome global warming and energy crisis. It is a clean energy source that could not only produce energy but also serve as a means of waste treatment. It is possible to produce more voltage if different individual fuel cells are arranged in series. There is an urgent need to give the special focus for the advanced research in this direction. The collective efforts of Chemists, Biochemists, Microbiologists, Environmental Engineers and some other disciplines in this area of research can produce the fruitful result for the development of novel technology of bioenergy around the globe. The results obtained have truly supported the thesis that microorganisms are capable of producing voltage (energy) via oxidation of the organic matter present in the wastewater.

\section{REFERENCES}

Abhilasha SM, Sharma VN. 2009. Production from various wastewaters through microbial fuel cell technology. Journal of Biochemical Technology, 2(1): 133-137.

Allen RM, Bennetto HP. 1993. Microbial fuel-cells: electricity production from 
carbohydrates. Applied Biochemistry and Biotechnology, 39: 27-40.

Bennetto HP. 1990. Electricity generation by microorganisms. Biotechnology Education, 1: 163-168.

Buchannan RE, Gibbon NE. 1974. Bergy's Manual of Determinative Bacteriology. Williams and wilkins Co.: Baltimore, U.S.A.

Cheesbrough M. 2000. District Laboratory Practice in Tropical Countries (part 2). Cambridge University Press: UK; 35-38, 62-69.

Chin-Tsan W, Wei-Jung CB, Ruei-Yao H. 2010. Influence of growth curve phase on electricity performance of microbial fuel cell by Escherichia coli. International Journal of Hydrogen Energy. 35: 7217 7223.

Dip M, Jyoti PM, Min-Jen T, Vanita RN, Hau-Ren C, Chien-Cheng C, Young-Fo C, Tsui-Chu Y, Chen-Yen C. 2014. Electricity Generation and Wastewater Treatment of Oil Refinery in Microbial Fuel Cells Using Pseudomonas putida. Int J. Mol. Sci., 15(9): 16772-16786.

Du Z, Li H, Gu TA. 2007. State of the art review on microbial fuel cells: A promising technology for wastewater treatment and bioenergy. Biotechnology Advances, 25: 464-482.

Feng Z, Robert CTS, John RV. 2008. Techniques for the study and development of microbial fuel cells: an electrochemical perspective. Chemical Sciences, University of Surrey: Guildford.

Ghangrekar MM, Shinde VB. 2006. Wastewater Treatment in Microbial Fuel Cell and Electricity Generation: A Sustainable Approach. Paper presented in the $12^{\text {th }}$ international sustainable development research conference. Hong Kong, April 6-8.
Gil GC, Chang IS, Kim BH, Kim M, Jang JK, Park HS, Kim HJ. 2003. Operational parameters affecting the performance of a mediator-less microbial fuel cell. Biosensors and Bioelectronics, 18(4): 327-334.

Jang JK, Pham TH, Chang IS, Kang KH, Moon H, Cho KS, Kim BH. 2004. Construction and operation of a novel mediator- and membrane-less microbial fuel cell. Process Biochem., 39: 10071012.

Jincheng W, Peng L, Xia H. (2011). Recent progress in electrodes for microbial fuel cells Bioresource Technology, 102: 9335-9344.

Kiely PD, Cusick R, Call DF, Selembo PA, Regan JM, Logan BE. 2011. Anode microbial communities produced by changing from microbial fuel cell to microbial electrolysis cell operation using two different wastewaters. Bioresour. Technol., 102:388-394.

Logan BE. 2007. Microbial Fuel Cells $\left(1^{\text {st }}\right.$ edn). Wiley and Sons: USA; 1-44.

McKellar R, Lu X. 2004. Modeling Microbial Responses on Foods. CRC Press: Boca Raton, FL.

Min B, Kim JR, Oh SE, Regan JM, Logan BE. 2005. Electricity generation from swine wastewater using microbial fuel cells. Water Research, 39: 4961-4968.

Moon H, Chang IS, Kim BH. 2006. Continuous electricity production from artificial wastewater using a mediator-less microbial fuel cell. Bioresource Technology, 97: 621-627.

Oh SE, Logan BE. 2005. Hydrogen and electricity production from a food processing wastewater using fermentation and microbial fuel cell technologies. Water Research, 39: 4673-4682.

Peleg M. 2006. Advanced Quantitative Microbiology for Food and Biosystems: 
Models for Predicting Growth and Inactivation. CRC Press: Boca Raton, FL. Sonal GC. 2014. Microbial Fuel cell: A New Approach of Wastewater Treatment with Power Generation. International Journal of Chemical, Environmental and Pharmaceutical Research, 5(1): 8-12.

Wen Q, Wu Y, Cao D, Zhao L, Sun Q. 2009. Electricity generation and modeling of microbial fuel cell from continuous beer brewery wastewater. Bioresour. Technol., 100: 4171-4175.

Wudneh AS, Subba RC, Jerald AL. 2014. Electricity Generation and Biofilm Formation in Microbial Fuel Cells Using Plate Anodes Constructed from Various
Grades of Graphite. Journal of Green Engineering, 4: 13-32.

Yongtae A, Marta C. Hatzell FZ, Logan BE (2014) Different electrode configurations to optimize performance of multielectrode microbial fuel cells for generating power or treating domestic wastewater. Journal of Power Sources 249: 440-445.

You SJ, Zhao QL, Jiang JQ, Zhang JN. 2006. Treatment of domestic wastewater with simultaneous electricity generation in microbial fuel cell under continuous operation. Chemical and Biochemical Engineering Q., 20(4): 407-412. 